\title{
ESTIMATION OF THE VARIANCE OF SOME EGYPTIAN COTTON GENOTYPES IN THE DELTA AND UPPER EGYPT USING DIFFERENT APPROACHES OF COMBINED ANALYSIS
}

( Received: 28 . 10. 2006 )

\author{
By \\ H. A. Idris and H. B. Abou Tour \\ Cotton Research Institute, Agricultural Research Center, Giza, Egypt.
}

\begin{abstract}
The present investigation is dealing with the variances of two groups of long staple Egyptian cotton (Gossypium barbadense L.) genotypes, with respect to yield, its components and fiber properties in the Delta and the valley during 2004 and 2005 seasons. The first group, viz. G.85, G.86, G.89 and G.89 x G.86 were evaluated in the Delta (Monofia and Gharbia). The second group, viz. G.80, G.83, G.90 and G.91 were evaluated in the valley (Assuit and Beni Souf). Randomized complete block design was used in each experiment. The final goal was to study the possibility of suggesting a modified analysis of randomized complete block design to replace the use of traditional combined analysis. In such proposal the data of the two groups of genotypes were used together. Two main locations were formed. The first, i.e. Delta locations included the data of Monofia and Gharbia Governorates. Gathering data of Assuit and Beni Souf formed the second one, i.e. valley. Thus, each main location (Delta or Valley) included the same number of replicates as in any Governorate due to each plot contained two readings $(\mathrm{k})$ one for each Governorate. Genotypes $(\mathrm{g})$ partitioning into two groups, viz. genotypes Delta (gd) and genotypes valley (gv). Modified surpassed combined due to it does not need to calculate homogeneity test of variances (Bartlett test) before the start of analysis. Modified analysis could estimate two groups of genotypes variance on one stage of analysis, while combined analysis could estimate the same results using two stages of analysis. Results exhibited modified made two directions of the analysis different both groups and locations, while combined made one direction of the analysis one group in different location. Modified could be calculated (gd) vs (gv) variance, while combined could not calculate. Although the two ways of analyses calculated the same value of variance for each group of genotypes but they exhibited different results of significant variation due to different values of $\mathrm{F}$ Table of them, which depend on the degree of freedom of the error.
\end{abstract}

Key words: combined analysis, cotton, delta, environments, randomized complete block design, valley locations.

\section{INTRODUCTION}

In a program of research it is quite common to repeat the same experiment at a number of different places, on a number of different occasions. There may be several reasons for this. Sometimes the object of the research is to produce recommendations, which are to apply to a population that is extensive either in space, in time or in both. Thus in agricultural field experimentation, many projects are undertaken in the hope that their results can be applied in practical farming. The conclusions drawn from such research, if they are to be of use, must be valid for at least several seasons in the future and over a reasonably large area of farmland. It has been found that the effectiveness of the common plant nutrients, of different varieties of a crop, and of different cultivation practices usually varies from field to other and, even more markedly, from season to season. A single experiment, however well conducted, supplies information about only one place and one season. Consequently, such experiments are carried out at several different places in the area for which the recommendations are wanted, and are repeated for a number of seasons. In other cases it may be interested, not in making inferences about some specific population, but in studying the influence of external conditions on some measurement or on the response to 
treatments. Sing and Narayanan (2000) agreed to the concept of applied randomized complete block design in plant breeding. The randomized complete block experiment is quite flexible. Since the variability between replications can be removed from the experimental error, it is not necessary for the replications to be continuous. An entire variable or replication may be omitted from an analysis when, for some reason, it either is lost or is not comparable with the others.

One of the jobs of the research stations is to develop high yielding cultivars and make them available to the growers. The productivity of cultivars, results to a large extent from how well it benefits from the environmental conditions. The attempt to adapt elements of the production system used in Egypt brought about plant breeding efforts to develop cottons suited to wider range of environments in Egyptian cotton belt.

Cultivar trials are an essential part of a breeding program prior to the release of a new cultivar. Usually, a number of locations and years are necessary to adequately evaluate cultivar performance. While some locational effects on cultivars may be predictable, yearly effects are usually considered to result from random fluctuations of weather variables, which in turn interact unpredictably with other environmental or biological factors.

Idris (1995) evaluated eleven Egyptian cotton cultivars in the Delta and Valley. The results of combined analysis exhibited yields (seed and lint), boll weight, seed index, lint percentage, fiber length, micronaire reading were significantly affected by the interaction between locations x cultivars. El Oraby (1998) evaluated 5 long Egyptian cotton genotypes, viz. G.75, G.85, G.80 and G.83 and G.89. in the Delta and Valley. The results of combined analysis exhibited that mean squares of genotypes with respect to boll weight, seed index and lint percentage differed significantly.

Awad et al. (2004) compared G.90 and G.83 with respect to yield and fiber in the Valley (Assuit and Sohag) in four seasons. The results exhibited that G.90 is characterized by about 5\% higher yields (seed and lint) than G.83.It slightly surpassed G.83 for boll weight and gave the same range of lint percentage of G.83. Fiber quality for G.90 was nealy the same for the long staple cotton group in the Valley. Idris (2005) evaluated 5 cotton genotypes, viz. G.80, G.83, G.90, G.81 x G.83 and G.89 x Pima
S-6 in Valley using combined randomized complete block design. The results showed significant variation due to genotypes for yield and its component except seed cotton yield in the first season. Significant differences due to the genotype $\mathrm{x}$ locations were also observed for lint percentage in the first season, boll weight in the second season and lint cotton yield in the two seasons. Mohamed (2005) evaluated 10 Egyptian cotton genotypes in the Delta using combined randomized complete block design. $\mathrm{He}$ found that the mean squares for genotypes $\mathrm{x}$ locations was significantly for yield (seed and lint), boll weight, lint percentage, fiber length and micronaire value.

The objective of the present study was to estimate some Egyptian cotton genotypes variance in the Delta and Valley using different approaches of combined analysis.

\section{MATERIALS AND METHODS}

Two field experiments were carried out in both the Delta (Monofia and Gharbia) and the Valley (Assuit and Beni Souf) in 2004 and 2005 seasons. The materials used in this study were two groups of long staple Egyptian cotton (Gossypium barbadense L.) genotypes. The first group (gd) (are normally grown in the Delta), viz. G.85, G.86, G.89 and G.89 x G.86 were evaluated in the Delta. The second group (gv) (are normally grown in Valley), viz. G.80, G.83, G.90 and G.91 were evaluated in the Valley. A randomized complete block design with five replications was used in each experiment. Planting was done during the last week of March. All other cultural practices were performed as usual.

Genotypes were evaluated for yield, its components and fiber properties. Yield and its components, viz. seed cotton yield (S.C.Y.) in kentar/ fed, lint cotton yield (L.C.Y.) in kentar/ fed, boll weight (B.W.) in gm, lint percentage (L.P.) $\%$ and seed index (S.I.) in gm. Fiber properties, viz. fiber length (F.L.)mm, micronaire reading (Mic.) and pressly index (P.I.).

\subsection{Statistical analysis}

\subsubsection{Traditional analysis of randomized complete block design}

The traditional analysis was carried out with the data of the four Governorates (individual Governorate) as previously mentioned in the two successive seasons to estimate genotypes variance in the Delta and Valley. Then, partitioning genotypes to linear and residual. 
Statistical analysis was conducted according to Cochran and Cox (1950) and Gomez and Gomez (1984).

\subsubsection{Combined analysis of randomized complete block design}

The traditional combined analysis was carried out with data of two Governorates (Delta and Valley). Combined analysis depends on one group of genotype and increased replicates to estimate genotype variance in the Delta and the Valley. Then, partitioning the genotypes to linear and residual, (Table 1). Homogeneity test of variances (Bartlett test) was used according to the procedures reported by Bailey (1994). All statistical procedures and methods were carried out according to Federer (1955) and Roger (1994). The treatment means were compared by L.S.D. test as given by Steel and Torrie (1980). All comparisons were done at 0.05 level of significance.
(Table 1). Statistical analysis was courried out according to Roger (1994). Homogeneity test of variances (Bartlett test) was not used before the analysis. The treatment means were compared by L.S.D. test as given by Steel and Torrie (1980). All comparisons were done at the 0.05 level of significance.

\section{RESULTS AND DISCUSSION \\ 3.1 Traditional analysis}

The analysis of variance for individual Governorate in the Delta and the Valley revealed significant variation due to replications, genotypes and partitioning of genotypes into linear and residual, (Tables 2 and 3).

\subsubsection{Delta (Monofia and Gharbia)}

No significant variation due to replications was observed for yield, its components and fiber properties except lint percentage in both Governorates. Significant difference due to

Table (1): Comparison between two analyses of randomized complete block design (combined and modified)



\subsubsection{Modified analysis of randomized} complete block design

A modified analysis suggested by the authors was used. In this proposal the data of the two groups of genotypes were used together. Two main locations were formed. The first, i.e. Delta locations included the data of Monofia and Gharbia Governorates. Collective data of Assuit and Beni Souf formed the second one, i.e. Valley. Thus, each main location (the Delta or the Valley) included the same number of replicates as in any Governorate due to each plot contained two readings (k) one for each Governorate. Genotypes (g) partitioning into two groups, viz. genotypes Delta (gd) and genotypes valley (gv) to estimate genotypes variance in Delta and Valley and comparison between the two groups of genotypes. Then partitioning genotypes to linear and residual, genotypes was detected on all traits in Monofia except lint cotton yield, seed index and pressly index. In contrast, genotypes exhibited nonsignificant variation with respect to yield, its components and fiber properties except lint percentage and fiber length in Gharbia. Results indicated that genotypes Delta exhibited different response in Delta. Significant variation due to linear was recorded for lint percentage in both Governorates and micronaire reading in Monofia. In both Governorates, results exhibited linear was similar except micronaire reading.

\subsubsection{Valley (Assuit and Beni Souf)}

In both Governorates, non-significant difference due to replications was observed for yield, its components and fiber properties except fiber length in Beni Souf Governorate. Significant difference due to genotypes was observed for all traits in the two Governorates 
Table (2): Mean Squares of yield and its components for individual Governorate in the Delta and the Valley.

\begin{tabular}{|c|c|c|c|c|c|c|}
\hline \multicolumn{7}{|c|}{ Delta } \\
\hline \multicolumn{7}{|c|}{ Monofia 2004 Season } \\
\hline \multicolumn{2}{|l|}{ Traits } & \multirow{2}{*}{$\begin{array}{l}\text { S.C.Y } \\
(\mathrm{k} / \mathrm{fed})\end{array}$} & \multirow{2}{*}{$\begin{array}{l}\text { L.C.Y } \\
\text { (k/fed) }\end{array}$} & \multirow{2}{*}{$\begin{array}{l}\text { B.W. } \\
\text { (gm) }\end{array}$} & \multirow{2}{*}{$\begin{array}{l}\text { L. P. } \\
(\%)\end{array}$} & \multirow{2}{*}{$\begin{array}{l}\text { S. I. } \\
\text { (gm) }\end{array}$} \\
\hline Source of variation & d.f. & & & & & \\
\hline Replications & 4 & 0.482 & 0.372 & 0.042 & $0.652 *$ & 0.215 \\
\hline Genotypes & 3 & $8.67 * *$ & 1.13 & $0.085^{*}$ & $2.46^{* *}$ & 1.05 \\
\hline Linear & 1 & 2.46 & 0.180 & 0.020 & $2.60 * *$ & 0.030 \\
\hline Residual & 2 & 11.78 & 1.61 & 0.120 & 2.38 & 1.57 \\
\hline \multirow{2}{*}{$\begin{array}{l}\text { Experimental error } \\
\text { Total }\end{array}$} & 12 & 0.672 & 0.805 & 0.019 & 0.173 & 0.360 \\
\hline & 19 & & & & & \\
\hline \multicolumn{7}{|c|}{ Gharbia 2005 Season } \\
\hline \multicolumn{2}{|l|}{ Traits } & \multirow{2}{*}{$\begin{array}{l}\text { S.C.Y } \\
\text { (k/fed) }\end{array}$} & \multirow{2}{*}{$\begin{array}{l}\text { L.C.Y } \\
\text { (k/fed) }\end{array}$} & \multirow{2}{*}{$\begin{array}{l}\text { B.W. } \\
\text { (gm) }\end{array}$} & \multirow{2}{*}{$\begin{array}{l}\text { L.P. } \\
(\%)\end{array}$} & \multirow{2}{*}{$\begin{array}{l}\text { S. I. } \\
\text { (gm) }\end{array}$} \\
\hline Source of variation & d.f & & & & & \\
\hline Replications & 4 & 0.974 & 1.39 & 0.021 & $1.70 *$ & 0.451 \\
\hline Genotypes & 3 & 0.951 & 2.76 & 0.047 & $9.72 * *$ & 0.469 \\
\hline Linear & 1 & 0.050 & 1.54 & 0.010 & $18.53 * *$ & 0.760 \\
\hline Residual & 2 & 1.40 & 3.37 & 0.065 & 5.31 & 0.320 \\
\hline \multirow{2}{*}{$\begin{array}{l}\text { Experimental error } \\
\text { Total }\end{array}$} & 12 & 0.412 & 0.866 & 0.041 & 0.503 & 0.246 \\
\hline & 19 & & & & & \\
\hline \multicolumn{7}{|c|}{ Valley } \\
\hline \multicolumn{7}{|c|}{ Assuit 2004 Season } \\
\hline \multicolumn{2}{|l|}{ Traits } & \multirow{2}{*}{$\begin{array}{l}\text { S.C.Y } \\
(\mathrm{k} / \mathrm{fed})\end{array}$} & \multirow{2}{*}{$\begin{array}{l}\text { L.C.Y } \\
\text { (k/fed) }\end{array}$} & \multirow{2}{*}{$\begin{array}{l}\text { B.W. } \\
\text { (gm) }\end{array}$} & \multirow{2}{*}{$\begin{array}{l}\text { L. P. } \\
(\%)\end{array}$} & \multirow{2}{*}{$\begin{array}{l}\text { S. I. } \\
\text { (gm) }\end{array}$} \\
\hline Source of variation & d.f. & & & & & \\
\hline Replications & 4 & 1.41 & 1.79 & 0.034 & 0.124 & 0.077 \\
\hline Genotypes & 3 & $9.45^{*}$ & $15.04 *$ & $0.116^{*}$ & 1.03 & $1.53 * *$ \\
\hline Linear & 1 & $18.45 * *$ & $34.52 * *$ & $0.250 *$ & 2.33 & $3.55 * *$ \\
\hline Residual & 2 & 4.95 & 5.30 & 0.050 & 0.380 & 0.520 \\
\hline \multirow{2}{*}{$\begin{array}{l}\text { Experimental error } \\
\text { Total }\end{array}$} & 12 & 2.28 & 3.83 & 0.032 & 0.533 & 0.197 \\
\hline & 19 & & & & & \\
\hline \multicolumn{7}{|c|}{ Beni Souf 2005 Season } \\
\hline Traits & & S.C.Y & L.C.Y & B.W. & L. $\mathbf{P}$. & S. I. \\
\hline Source of variation & d.f. & (k/fed) & $(\mathbf{k} / \mathbf{f e d})$ & (gm) & $(\%)$ & (gm) \\
\hline Replications & 4 & 0.067 & 0.812 & 0.006 & 0.128 & 0.116 \\
\hline Genotypes & 3 & $7.12 * *$ & $11.54 * *$ & $0.183 * *$ & $4.47 * *$ & $1.20 * *$ \\
\hline Linear & 1 & 1.36 & $7.72 *$ & 0.001 & $13.03 * *$ & $3.28 * *$ \\
\hline Residual & 2 & 10.00 & 13.43 & 0.275 & 0.190 & 0.165 \\
\hline Experimental error & 12 & 0.856 & 0.889 & 0.012 & 0.160 & 0.173 \\
\hline Total & 19 & & & & & \\
\hline
\end{tabular}

Table (3): Mean Squares of fiber properties for individual Governorate in the Delta and the Valley.

\begin{tabular}{|c|c|c|c|c|c|c|c|}
\hline \multirow{3}{*}{\multicolumn{2}{|c|}{ Traits }} & \multicolumn{6}{|c|}{ Delta } \\
\hline & & \multicolumn{3}{|c|}{ Monofia 2004 Season } & \multicolumn{3}{|c|}{ Gharbia 2005 Season } \\
\hline & & \multirow{2}{*}{$\begin{array}{l}\text { F.L. } \\
(\mathbf{m m})\end{array}$} & \multirow{2}{*}{ Mic. } & \multirow{2}{*}{ P.I. } & \multirow{2}{*}{$\begin{array}{l}\text { F.L. } \\
(\mathbf{m m})\end{array}$} & \multirow{2}{*}{ Mic. } & \multirow{2}{*}{ P.I. } \\
\hline Source of variation & d.f. & & & & & & \\
\hline Replications & 4 & 0.702 & 0.053 & 0.101 & 0.724 & 0.027 & 0.413 \\
\hline Genotypes & 3 & $5.53 *$ & $0.372 * *$ & 0.395 & $5.56 *$ & 0.197 & 1.25 \\
\hline Linear & 1 & 2.92 & $0.610 * *$ & 0.062 & 4.93 & 0.190 & 0.578 \\
\hline Residual & 2 & 3.84 & 0.255 & 0.562 & 5.87 & 0.200 & 1.58 \\
\hline \multirow{2}{*}{$\begin{array}{l}\text { Experimental error } \\
\text { Total }\end{array}$} & 12 & 0.737 & 0.050 & 0.276 & 1.04 & 0.066 & 0.653 \\
\hline & 19 & & & & & & \\
\hline & & \multicolumn{6}{|c|}{ Valley } \\
\hline \multirow{2}{*}{\multicolumn{2}{|c|}{ Traits }} & \multicolumn{3}{|c|}{ Assuit 2004 Season } & \multicolumn{3}{|c|}{ Beni Souf 2005 Season } \\
\hline & & \multirow{2}{*}{$\begin{array}{l}\text { F.L. } \\
(\mathbf{m m})\end{array}$} & \multirow[t]{2}{*}{ Mic. } & \multirow[t]{2}{*}{ P.I. } & \multirow{2}{*}{$\begin{array}{l}\text { F.L. } \\
(\mathbf{m m})\end{array}$} & \multirow[t]{2}{*}{ Mic. } & \multirow[t]{2}{*}{ P.I. } \\
\hline Source of variation & d.f. & & & & & & \\
\hline Replications & 4 & 0.369 & 0.068 & 0.116 & $1.16^{*}$ & 0.052 & 0.275 \\
\hline Genotypes & 3 & $6.57 * *$ & $0.647 * *$ & 0.324 & $0.979 *$ & $0.258^{*}$ & $1.63 * *$ \\
\hline Linear & 1 & $16.48 * *$ & 0.010 & 0.640 & 0.500 & $0.608 * *$ & $2.82 * *$ \\
\hline Residual & 2 & 1.61 & 0.960 & 0.166 & 1.22 & 0.085 & 1.04 \\
\hline \multirow{2}{*}{$\begin{array}{l}\text { Experimental error } \\
\text { Total }\end{array}$} & 12 & 0.754 & 0.025 & 0.261 & 0.222 & 0.061 & 0.124 \\
\hline & 19 & & & & & & \\
\hline
\end{tabular}

**** Significant at 0.05 and 0.01 levels , respectively. 
except lint percentage and pressly index in Assuit. Genotypes Valley exhibited similar results with respect to significant variation except two characters indicating that responses of genotypes were the same in the Valley.

Significant variation due to linear was observed for lint cotton yield and seed index in the two Governorates.

\subsection{Combined analysis}

Combined analysis could estimate two groups of genotypes variance on the two stages due to analyzing each group alone. The analysis of variance showed significant variation due to locations, genotypes, partitioning of genotypes into linear and residual and (genotypes $\mathrm{x}$ locations) in the Delta and the Valley, (Tables 4 and 5).

\subsubsection{Delta}

Significant difference due to locations was observed for all characters except micronaire value indicating that all traits were highly affected by locations.

Non significant variation due to linear was recorded for yield and its components and fiber properties except lint percentage and pressly index. Except two traits, viz. seed cotton yield and lint percentage non-significant differences were recorded due to genotypes $\mathrm{x}$ locations.

\subsubsection{Valley}

Significant variations due to locations and genotypes were detected on yield (seed and lint), its components and fiber properties except pressly index with respect to locations. Results of linear were different from Delta because significant differences were detected on all

Table (4): Mean Squares of yield and its components in the Delta and the Valley (Combined analysis).

\begin{tabular}{|c|c|c|c|c|c|c|}
\hline \multicolumn{7}{|c|}{ Delta } \\
\hline \multicolumn{2}{|l|}{ Traits } & \multirow{2}{*}{$\begin{array}{l}\text { S.C.Y. } \\
\text { (k/fed) }\end{array}$} & \multirow{2}{*}{$\begin{array}{l}\text { L.C.Y. } \\
\text { (k/fed) }\end{array}$} & \multirow{2}{*}{$\begin{array}{l}\text { B.W. } \\
\text { (gm) }\end{array}$} & \multirow{2}{*}{$\begin{array}{l}\text { L.P. } \\
(\%)\end{array}$} & \multirow{2}{*}{$\begin{array}{l}\text { S. I. } \\
\text { (gm) }\end{array}$} \\
\hline Source of variation & d.f. & & & & & \\
\hline Locations (L) & 1 & $211.09 * *$ & $203.76^{* *} *$ & $0.365^{*}$ & $8.27 *$ & $4.65 * *$ \\
\hline Rep. / Locations & 8 & 0.728 & 0.881 & 0.031 & 1.18 & 0.333 \\
\hline Genotypes (G) & 3 & $5.44 * *$ & 2.09 & 0.060 & $10.71 * *$ & $1.27 *$ \\
\hline Linear & 1 & 1.61 & 0.335 & 0.028 & $17.52 * *$ & 0.535 \\
\hline Residual & 2 & 7.36 & 2.97 & 0.075 & 7.31 & 1.64 \\
\hline \multirow{3}{*}{$\begin{array}{l}\text { Gx L } \\
\text { Experimental error } \\
\text { Total }\end{array}$} & 3 & $4.19 * *$ & 1.80 & 0.072 & $1.46^{*}$ & 0.245 \\
\hline & 24 & 0.542 & 0.836 & 0.030 & 0.339 & 0.303 \\
\hline & 39 & & & & & \\
\hline \multicolumn{7}{|c|}{ Valley } \\
\hline \multicolumn{2}{|l|}{ Traits } & \multirow{2}{*}{$\begin{array}{l}\text { S.C.Y. } \\
\text { (k/fed) }\end{array}$} & \multirow{2}{*}{$\begin{array}{l}\text { L.C.Y. } \\
\text { (k/fed) }\end{array}$} & \multirow{2}{*}{$\begin{array}{l}\text { B.W. } \\
\text { (gm) }\end{array}$} & \multirow{2}{*}{$\begin{array}{c}\text { L.P. } \\
(\%)\end{array}$} & \multirow{2}{*}{$\begin{array}{l}\text { S. I. } \\
\text { (gm) }\end{array}$} \\
\hline Source of variation & d.f. & & & & & \\
\hline Locations (L) & 1 & $89.43 * *$ & $100.30 * *$ & $1.01 * *$ & $0.858 *$ & $12.93 * *$ \\
\hline Rep. / Locations & 8 & 0.738 & 1.30 & 0.020 & 0.125 & 0.096 \\
\hline Genotypes (G) & 3 & $14.40 * *$ & $24.36 * *$ & $0.187 * *$ & $4.64 * *$ & $2.36 * *$ \\
\hline Linear & 1 & $14.91 * *$ & $37.45 * *$ & $0.129 *$ & $13.19 * *$ & $6.83 * *$ \\
\hline Residual & 2 & 14.14 & 17.81 & 0.217 & 0.371 & 0.125 \\
\hline \multirow{3}{*}{$\begin{array}{l}\text { Gx L } \\
\text { Experimental error } \\
\text { Total }\end{array}$} & 3 & 2.17 & 2.22 & $0.122 * *$ & 0.858 & 0.374 \\
\hline & 24 & 1.57 & 2.36 & 0.022 & 0.347 & 0.185 \\
\hline & 39 & & & & & \\
\hline
\end{tabular}

Table (5): Mean Squares of fiber properties in the Delta and the Valley (Combined analysis).

\begin{tabular}{|c|c|c|c|c|c|c|c|}
\hline \multirow{2}{*}{\multicolumn{2}{|c|}{ Traits }} & \multicolumn{3}{|c|}{ Delta } & \multicolumn{3}{|c|}{ Valley } \\
\hline & & \multirow{2}{*}{$\begin{array}{l}\text { F.L. } \\
(\mathbf{m m})\end{array}$} & \multirow[t]{2}{*}{ Mic. } & \multirow[t]{2}{*}{ P.I. } & \multirow{2}{*}{$\begin{array}{l}\text { F.L. } \\
(\mathbf{m m})\end{array}$} & \multirow[t]{2}{*}{ Mic. } & \multirow[t]{2}{*}{ P.I. } \\
\hline Source of variation & d.f. & & & & & & \\
\hline Locations $(\mathrm{L})$ & 1 & $4.69 *$ & 0.036 & $2.65^{*}$ & $29.76^{* *}$ & $3.72 * *$ & 0.484 \\
\hline Rep. / Locations & 8 & 0.713 & 0.040 & 0.257 & 0.763 & 0.060 & 0.195 \\
\hline Genotypes (G) & 3 & $8.87 * *$ & $0.473 * *$ & 1.20 & $5.65 * *$ & $0.594 * *$ & $1.21 * *$ \\
\hline Linear & 1 & $7.72 * *$ & $0.744 * *$ & 0.510 & $11.38 * *$ & $0.405 * *$ & $3.08 * *$ \\
\hline \multirow{4}{*}{$\begin{array}{l}\text { Gx L } \\
\text { Experimental error } \\
\text { Total }\end{array}$} & 2 & 9.45 & 0.537 & 1.54 & 2.78 & 0.690 & 0.274 \\
\hline & 3 & 0.214 & 0.097 & 0.442 & $1.90 *$ & $0.311 * *$ & $0.749 *$ \\
\hline & 24 & 0.886 & 0.058 & 0.465 & 0.488 & 0.043 & 0.193 \\
\hline & 39 & & & & & & \\
\hline
\end{tabular}

*, ** Significant at 0.05 and 0.01 levels, respectively. 
characters yield and fiber. Significant difference due to genotypes $\mathrm{x}$ locations was observed for all fiber characters and boll weight.

\subsection{Modified analysis}

Modified analysis could estimate two groups of genotype variance on one stage due to using two groups of genotypes in the analysis. The analysis of variance for both locations and genotype within Delta and Valley revealed significant variation due to replications, genotypes and partitioning of them, (Table 6).

Significant variation due to genotypes was observed for yield, its components and fiber properties due to the different two groups of genotypes. Both genotypes (gd) and (gv) exhibited significant differences with respect to

Table (6): Mean Squares of yield, its components and fiber properties in the Delta and the Valley (Modified analysis).

\begin{tabular}{|c|c|c|c|c|c|c|}
\hline \multicolumn{2}{|l|}{ Traits } & \multirow{2}{*}{$\begin{array}{l}\text { S.C.Y. } \\
\text { (k/fed) }\end{array}$} & \multirow{2}{*}{$\begin{array}{l}\text { L.C.Y. } \\
\text { (k/fed) }\end{array}$} & \multirow{2}{*}{$\begin{array}{l}\text { B.W. } \\
\text { (gm) }\end{array}$} & \multirow{2}{*}{$\begin{array}{l}\text { L.P. } \\
(\%)\end{array}$} & \multirow{2}{*}{$\begin{array}{l}\text { S. I. } \\
\text { (gm) }\end{array}$} \\
\hline Source of variation & d.f. & & & & & \\
\hline Replications & 4 & 1.09 & 2.57 & 0.007 & 0.671 & 0.146 \\
\hline Genotypes & 7 & $18.50 * *$ & $18.19 * *$ & $0.421 * *$ & $8.74 * *$ & $3.06 * *$ \\
\hline Genotypes Delta & 3 & $5.44 * *$ & 2.09 & 0.060 & $10.71 * *$ & $1.27 * *$ \\
\hline Linear & 1 & 1.61 & 0.335 & 0.028 & $17.52 * *$ & 0.535 \\
\hline Residual & 2 & 7.36 & 2.97 & 0.075 & 7.31 & 1.64 \\
\hline Genotypes Valley & 3 & $14.40 * *$ & $24.36 * *$ & $0.187 * *$ & $4.64 * *$ & $2.36 * *$ \\
\hline Linear & 1 & $14.91 * *$ & $37.45^{* *}$ & $0.129 *$ & $13.19 * *$ & $6.83 * *$ \\
\hline Residual & 2 & 14.14 & 17.81 & 0.217 & 0.371 & 0.125 \\
\hline Delta vs Valley & 1 & $69.98 * *$ & $47.99 * *$ & $2.20 * *$ & $15.10^{* *}$ & $10.51 * *$ \\
\hline Experimental error & 28 & 0.926 & 0.952 & 0.029 & 0.399 & 0.202 \\
\hline Sampling error & 40 & 8.79 & 9.34 & 0.069 & 0.728 & 0.708 \\
\hline Genotypes Delta & 20 & 11.86 & 11.19 & 0.052 & 1.07 & 0.564 \\
\hline G.85 & 5 & 13.37 & 9.79 & 0.059 & 0.243 & 0.518 \\
\hline G.86 & 5 & 4.39 & 7.48 & 0.040 & 0.478 & 0.765 \\
\hline G.89 & 5 & 17.62 & 16.77 & 0.019 & 1.65 & 0.438 \\
\hline G.89 x G.86 & 5 & 12.05 & 10.73 & 0.089 & 1.91 & 0.532 \\
\hline Genotypes Valley & 20 & 5.72 & 7.48 & 0.086 & 0.384 & 0.854 \\
\hline G.80 & 5 & 8.98 & 11.63 & 0.131 & 0.718 & 1.26 \\
\hline G.83 & 5 & 7.88 & 11.51 & 0.105 & 0.222 & 0.483 \\
\hline G.90 & 5 & 2.66 & 3.18 & 0.006 & 0.290 & 0.865 \\
\hline \multirow[t]{2}{*}{ G.91 } & 5 & 3.38 & 3.59 & 0.101 & 0.306 & 0.808 \\
\hline & 79 & & & & & \\
\hline \multicolumn{2}{|l|}{ Traits } & F.L. & Mic. & P.I. & & \\
\hline Source of variation & d.f. & $(\mathbf{m m})$ & & & & \\
\hline Replications & 4 & 0.458 & 0.004 & 0.148 & & \\
\hline Genotypes & \multirow{2}{*}{$\begin{array}{l}73 \\
3\end{array}$} & $19.25 * *$ & $0.459 * *$ & $1.03 *$ & & \\
\hline Genotypes Delta & & $8.87 * *$ & $0.473 * *$ & $1.20^{*}$ & & \\
\hline Linear & 1 & $7.72 * *$ & $0.744 * *$ & 0.510 & & \\
\hline Residual & \multirow[b]{2}{*}{3} & 9.45 & 0.537 & 1.54 & & \\
\hline Genotypes Valley & & $5.65 * *$ & $0.594 * *$ & $1.21 *$ & & \\
\hline Linear & 1 & $11.38 * *$ & $0.405 *$ & $3.08 * *$ & & \\
\hline Residual & \multirow{2}{*}{$1^{2}$} & 2.78 & 0.690 & 0.274 & & \\
\hline Delta vs Valley & & $91.16 * *$ & 0.012 & 0.021 & & \\
\hline Experimental error & $28^{1}$ & 0.910 & 0.064 & 0.336 & & \\
\hline Sampling error & 40 & 1.46 & 0.160 & 0.402 & & \\
\hline Genotypes Delta & 20 & 0.657 & 0.049 & 0.518 & & \\
\hline G.85 & 5 & 0.522 & 0.061 & 0.465 & & \\
\hline G.86 & 5 & 0.709 & 0.036 & 0.818 & & \\
\hline G.89 & 5 & 0.123 & 0.024 & 0.341 & & \\
\hline G.89 x G.86 & 5 & 1.28 & 0.073 & 0.445 & & \\
\hline Genotypes Valley & 20 & 2.26 & 0.271 & 0.288 & & \\
\hline G.80 & 5 & 4.29 & 0.558 & 0.287 & & \\
\hline G.83 & 5 & 2.87 & 0.149 & 0.442 & & \\
\hline G.90 & 5 & 1.01 & 0.044 & 0.407 & & \\
\hline \multirow[t]{2}{*}{ G.91 } & 5 & 0.851 & 0.333 & 0.014 & & \\
\hline & 79 & & & & & \\
\hline
\end{tabular}


yield, its components and fiber properties except lint cotton yield and boll weight for genotypes (gd).

Significant variation due to genotypes Delta vs genotypes Valley was detected on all characters yield, its components and fiber.

No significant variation due to linear was observed for yield, its components and fiber properties except lint percentage, fiber length and micronaire reading with respect to genotypes Delta. In contrast, significant variation due to linear was detected on all traits with respect to genotypes Valley. Such results indicate different behavior between the two groups of genotypes (Table 7). slightly affected by different environments in Delta. G.89 showed the lowest values of variance with respect to fiber properties and yield components except boll weight in Delta. On the other hand, G.90 had the lowest values of variance among genotypes Valley with respect to yield, (seed and lint), boll weight, and micronaire reading indicating that it was slightly affected by different environments and in Valley. G.83 surpassed the other genotypes for showing lower variances with respect to two traits, viz. lint percentage and seed index, while G.91 did the same on fiber length and pressly index in the Valley.

Table (7): Means of yield, its components and fiber properties in the Delta and the Valley (combined and modified).

\begin{tabular}{|c|c|c|c|c|c|}
\hline$\frac{\text { Traits }}{\text { Genotypes }}$ & $\begin{array}{l}\text { S.C.Y. } \\
\text { (k/fed) }\end{array}$ & $\begin{array}{l}\text { L.C.Y. } \\
\text { (k/fed) }\end{array}$ & $\begin{array}{l}\text { B.W. } \\
\text { (gm) }\end{array}$ & $\begin{array}{c}\text { L.P. } \\
(\%)\end{array}$ & $\begin{array}{l}\text { S. I. } \\
\text { (gm) }\end{array}$ \\
\hline Genotypes Delta & & & & & \\
\hline G.85 & 12.33 & 14.53 & 2.87 & 40.64 & 10.18 \\
\hline G.86 & 10.89 & 13.76 & 3.01 & 40.22 & 10.59 \\
\hline G.89 & 12.03 & 13.56 & 2.88 & 38.31 & 9.96 \\
\hline G.89 x G.86 & 12.54 & 14.32 & 3.00 & 39.30 & 10.73 \\
\hline $\bar{x}$ & 11.95 & 14.04 & 2.94 & 39.62 & 10.37 \\
\hline L.S.D. Combined & 0.68 & ---- & ---- & 0.54 & 0.51 \\
\hline L.S.D. Modified & 1.25 & ---- & ---- & 0.82 & 0.58 \\
\hline Genotypes Valley & & & & & \\
\hline G.80 & 11.12 & 14.19 & 2.74 & 39.42 & 10.27 \\
\hline G.83 & 9.38 & 11.68 & 2.48 & 39.06 & 9.75 \\
\hline G.90 & 11.06 & 13.35 & 2.71 & 38.69 & 9.38 \\
\hline G.91 & 8.74 & 10.75 & 2.49 & 37.83 & 9.17 \\
\hline $\bar{x}$ & 10.08 & 12.49 & 2.61 & 38.75 & 9.64 \\
\hline L.S.D. Combined & 1.16 & 1.42 & 0.14 & 0.54 & 0.40 \\
\hline L.S.D. Modified & 1.25 & 1.26 & 0.22 & 0.82 & 0.58 \\
\hline Traits & \multirow{2}{*}{$\begin{array}{l}\text { F.L. } \\
\text { (mm) }\end{array}$} & \multirow[t]{2}{*}{ Mic. } & \multirow[t]{2}{*}{ P.I. } & & \\
\hline Genotypes & & & & & \\
\hline Genotypes Delta & & & & & \\
\hline G.85 & 29.92 & 4.07 & 9.93 & & \\
\hline G.86 & 32.07 & 4.54 & 10.20 & & \\
\hline G.89 & 31.71 & 4.44 & 9.37 & & \\
\hline G.89 x G.86 & 31.35 & 4.51 & 9.87 & & \\
\hline $\bar{x}$ & 31.26 & 4.39 & 9.84 & & \\
\hline L.S.D. Combined & 0.87 & 0.22 & ---- & & \\
\hline L.S.D. Modified & 1.24 & 0.33 & 0.75 & & \\
\hline Genotypes Valley & & & & & \\
\hline G.80 & 30.25 & 4.48 & 10.31 & & \\
\hline G.83 & 28.85 & 4.13 & 9.76 & & \\
\hline G.90 & 28.70 & 4.34 & 9.65 & & \\
\hline G.91 & 28.71 & 4.71 & 9.52 & & \\
\hline $\bar{x}$ & 29.13 & 4.42 & 9.81 & & \\
\hline L.S.D. Combined & 0.64 & 0.19 & 0.41 & & \\
\hline L.S.D. Modified & 1.24 & 0.33 & 0.75 & & \\
\hline
\end{tabular}

----, Not significant at 0.05 level.

G.86 had the lowest values of variance as compared to other genotypes Delta with respect to yield (seed and lint) indicating that it was
3.4 Comparison between combined and modified analyses 
Modified analysis surpassed combined one due to it does not need to calculate homogeneity test of variances (Bartlett test) before the start of analysis.

Modified analysis could estimate two groups of genotype variance in one stage due to using two groups of genotypes in the analysis. Combined analysis could estimate two groups of genotypes variance on the two stages due to analysing each group alone. These results exhibited modified made two directions of the analysis different both groups and locations, while combined made one direction of the analysis one group in different location.

Modified could be calculated (gd) vs (gv) variance, while combined could not calculated that.

Modified depends on a reduced number of replications. In contrast, combined depends on increasing the number of replications.

Degree of freedom of experimental error in modified was bigger than combined. Although the two ways of analyses calculated the same value of variance for each group of genotypes but they exhibited different results of significant variation due to different values of $F$ Table of them, which depends on degree of freedom of error.

Modified used one value of L.S.D. to compare within two gropes of genotypes, while combined used two values of L.S.D. one for each group.

\section{REFERENCES}

Awad H.Y., Awaad M.M., Mohamed S.A. , El Adly H.H., El Ameen T.M., Mohamed A.A. and Eissa A.E. (2004). Giza 90, a new , long staple Egyptian cotton variety for Middle and Upper Egypt. Egyptain Journal of Agricultural Research Center, 82 (3) 13491361.
Bailey N. T. (1994). Statistical Methods in Biology. Third Edit. Cambridge University Press, Cambridge, England.

Cochran W.G. and Cox G. W. (1950). Experimental Designs. John Wiley and Sons, New York., U.S.A.

El Oraby S.H. (1998). Studies on Yield of Some Egyptian Cotton Varieties Under Different Environments. M.Sc. Thesis, Kafr El Sheikh, Tanta Univ., Egypt.

Federer W. T. (1955). Experimental Design Theory and Application. The Macmillan Company New York, U.S.A.

Gomez K. A. and Gomez A. A. (1984). Statistical Procedures for Agricultural Research. Wiley, New York, U.S.A..

Idris H. A. (1995). Parametric Evaluation of Some Factors Affecting the Productivity Behaviour and Yield Declination of Some Egyptian Cotton Cultivars Under Different Environmental Conditions. M.Sc. Thesis, Fac., of Agric., Cairo Univ., Egypt.

Idris H. A. (2005). Evaluating some Egyptian cotton genotypes by using two steps of randomized complete block design and cluster analysis. Bull. Fac. Agric. Cairo Univ., 56 (4): 767-778.

Mohamed S. A. (2005). Evaluation of Some Genotypes in Egyptian Cotton at Different Locations. M.Sc. Thesis, Kafr El Sheikh, Tanta Univ., Egypt.

Roger G. P. (1994). Agricultural Field Experiments Design and Analysis. Marcel Dekker, Inc. New york, U.S.A.

Sing P., and Narayanan S. S. (2000). Biometrical Techniques in Plant Breeding. Second Edit., Ludhiana, New Delhi. India.

Steel R. G. and Torrie J. H. (1980). Principles and Procedures of Statistics. Second Edit., McGraw. Hill. Book Co. New York, U.S.A.






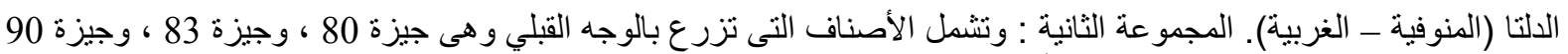

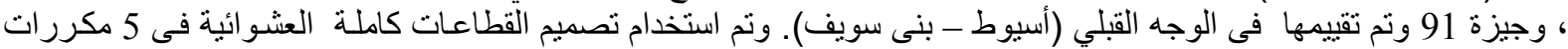
ل أكل تجربة. أولا : أجرى التحليل الإحصائي بالنسبة للتحليل التجميعي وفق الأسس المعروفة لكل من التراكيب الوراثية فى الدلتا ثم أجرى مرة

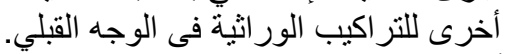

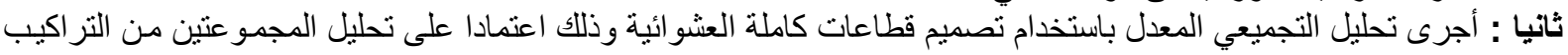

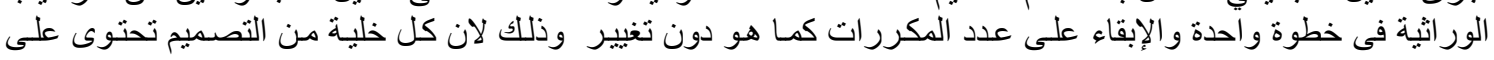
قر اعتين. وقد أظهرت النتائج مايلى: 1- تفوق التحليل المعدل على التقليدي بإمكانيته تحليل مجمو عتين من التر اكيب الور اثيـة كل مجموعـة قيمـة في منـاطق مختلفة عن

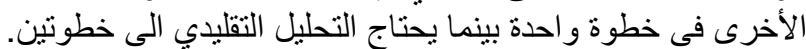

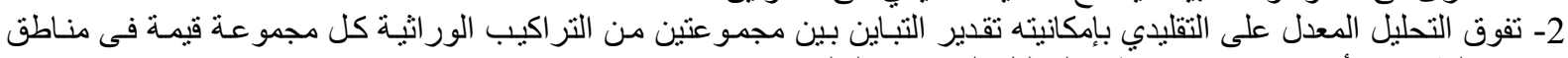

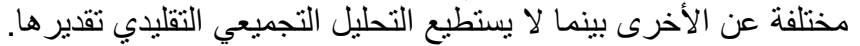

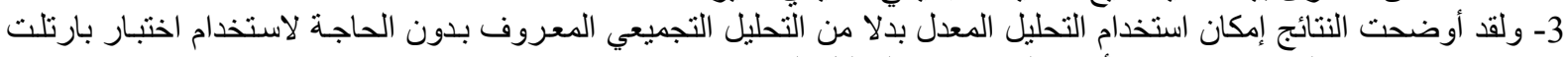

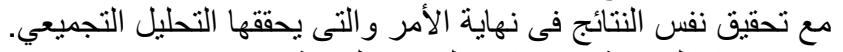

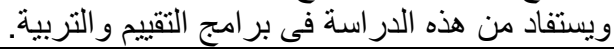
المجلة العلمية لكلية الزر اعة - جامعة القاهرة - المجلد (58) العدد الثالث (يوليو 2007):179- 187. 